\title{
Article
}

\section{Biogeography of bacterioplankton in inland waters}

\author{
Jürg Brendan Logue and Eva S. Lindström* \\ Department of Ecology and Evolution/Limnology, Box 573, SE-751 23 Uppsala, Sweden
}

*Corresponding author: Eva.Lindstrom@ebc.uu.se. Authors have contributed equally to the publication.

Received 12 September 2007; accepted 24 January 2008; published 22 April 2008

\section{Abstract}

Bacteria are among the most abundant groups of organisms. They mediate key ecological processes. Recent molecular advances have provided greater insight into bacterial diversity as well as allowing a more thorough examination of patterns in the spatial and temporal distribution of bacteria. Thus, the study of bacterial biodiversity and biogeographical distribution has stimulated considerable interest and dispute over the last decade.

This review summarises the findings obtained from studies on the biogeography of bacterioplankton in inland waters. We examine factors and processes that may determine and maintain bacterial diversity and biogeography, and relate these to the theoretical metacommunity framework.

We conclude that the importance of local environmental factors (such as lake character) for local bacterioplankton community compositions (BCC) is much more intensively studied than the importance of regional factors, such as dispersal. Further, few attempts have been made to evaluate simultaneously the relative importance of the two types of factors for BCC. Finally, we summarise gaps in knowledge, delineate challenges and put forward possible future research directions.

Keywords: Biogeography; bacterioplankton; microbial ecology; aquatic microbiology; metacommunities; diversity; review.

\section{Introduction}

One of the primary goals of ecology is to comprehend biodiversity and its pattern of spatial (biogeography) and temporal distribution. In order to preserve the world's biological variety, the principles governing diversity must be grasped and the underlying factors affecting patterns of species distribution and abundance need to be understood.
Considering that bacteria not only are ubiquitous but are also among the most abundant organisms on Earth (e.g. Curtis et al., 2002; Forney et al., 2004) and, even more importantly, that they are key players in biogeochemical and metabolic processes, they should play a decisive role in the biodiversity and biogeography debate. Aiming at revealing where organisms live, at what abundance and why, the study of biogeography provides insight into the mechanisms that constitute and maintain diversity, such as speciation, extinction, dispersal and 
species interactions. In this regard, the elucidation of biological and physicochemical factors controlling the community structure of bacteria is of great interest. However, unlike the studies of biogeographical patterns of animals and plants, the spatial and temporal scaling of bacterial diversity has hitherto received little attention (Martiny et al., 2006). This can be explained, at least partially, by methodological limitations as the investigation of bacterial diversity has been and still is a methodological challenge (for more thorough discussions about current methodological limitations, see e.g. Forney et al., 2004; Nocker et al., 2007). Whether or not the distribution of bacterial groups and species in nature conforms to explicable biogeographical patterns, like those of animals and plants, is at present greatly debated (Martiny et al., 2006; Horner-Devine et al., 2007; Prosser et al., 2007). To draw meaningful future conclusions, data must be gathered and interpreted; this is why studies of microbial biogeography are of substantial current interest.

The study of microbial biogeography has, for a long time, been influenced by the early view that 'everything is everywhere, but the environment selects' (Beijerinck, 1913; Baas-Becking, 1934), which claims that microbial taxa exist all over the world and thrive where specific habitat requirements are met. From studies of marine bacterioplankton communities, it seems that a few bacterial groups or clusters (the alphaproteobacterial SAR11 and Roseobacter clusters) feature an almost worldwide distribution alongside high abundances (Giovannoni et al., 1990; Morris et al., 2002; Selje et al., 2004). Inland waters show a more complex picture, as no specific group or cluster shows an equally dominating distribution. Zwart et al. (2002), however, identified 34 clusters which were dominated by or restricted to freshwater bacteria. The members of these groups also appear to exhibit a global distribution, whereupon the term 'typical freshwater bacterioplankton' was coined (Zwart et al., 2002). These findings of globally distributed taxa may be seen as supporting the Beijerinck and Baas-Becking hypothesis. However, in studies of bacterioplankton biogeography, other patterns have also emerged.
In this review we compile findings of biogeographical patterns in bacterioplankton diversity and discuss them in relation to theoretical models of biogeography. We address questions such as: 1. What kinds of spatial and temporal patterns in bacterioplankton community composition (BCC) have been identified and how can these patterns be explained?

2. How can mechanistic insights be obtained, patterns generalised, and predictions made by applying theoretical models?

3. Where do the gaps in knowledge lie today?

For simplicity, we restrict our discussion to bacteria, thereby excluding Archaea. Also, our focus is on bacterioplankton, so sediment and biofilm bacteria are, mostly, not discussed. Finally, the words 'diversity' and 'biodiversity' are used in a broad sense, referring to the number of taxa as well as their abundance and individual identity.

\section{Theoretical concepts}

The interpretation of biogeographical data as well as the design of investigative studies require a theoretical foundation providing structure and mechanistic insight and, eventually, predictability of natural assemblages (e.g. Prosser et al., 2007). Within the last decade, a new conceptual framework of community ecology - called the metacommunity concept (see Leibold et al., 2004 for a detailed review) - has evolved and, to an extent, been applied to microbial ecology.

A metacommunity is defined as a set of local communities that are linked by dispersal (Hanski \& Gilpin, 1991). The theory of metacommunity focuses on structural and dynamic processes emerging at different spatial scales (local as well as regional). In contrast, formal community theory operated on a single scale, presuming local communities to be shaped by local contemporary environmental conditions. The spatial dynamics within a metacommunity can alter local community structure by changing processes on a local scale, which in turn feed back to modify characteristics of the regional biota (Holyoak et al., 2005). Thus, 
processes acting on diversity within the local scale can be counteracted by processes acting within the regional scale.

The metacommunity framework comprises four simplified conceptual models, elucidating spatial community dynamics (e.g. Leibold et al., 2004; Holyoak et al., 2005): patch dynamics, species sorting, mass effects, and neutral.
The patch dynamic perspective (Fig. 1) assumes the existence of multiple identical patches, each being capable of sustaining a population. The patches may be occupied or unoccupied. They further undergo stochastic as well as deterministic extinctions. Dispersal, however, counteracts these extinctions by providing a source of colonisation into empty patches. Consequently, community structure will not depend on environmental characters

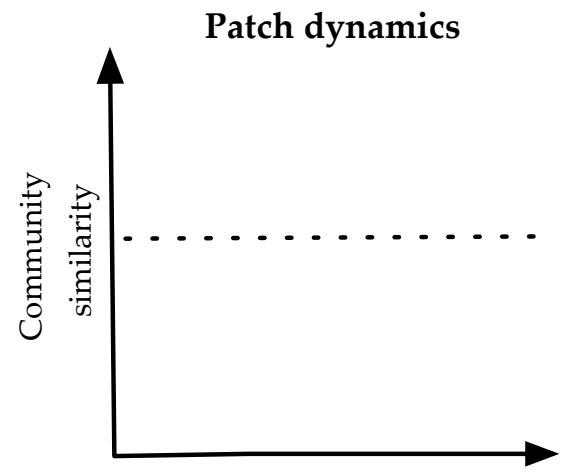

Distance

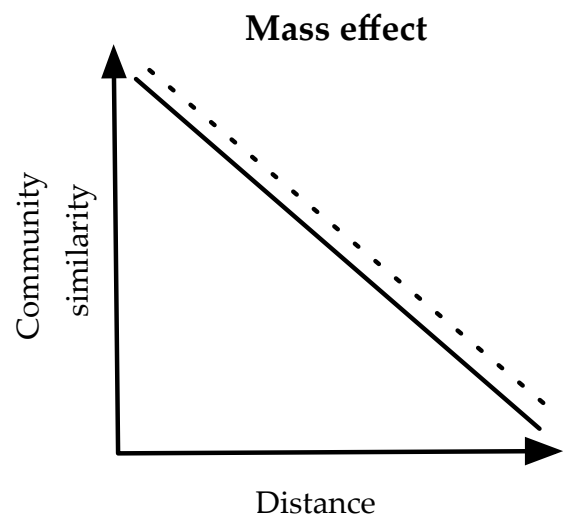

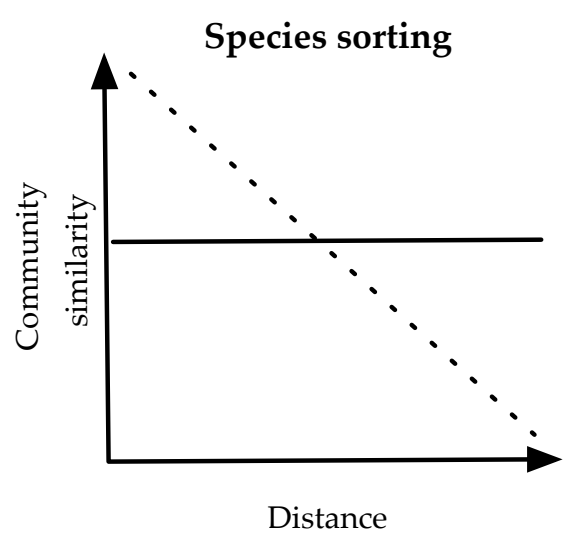

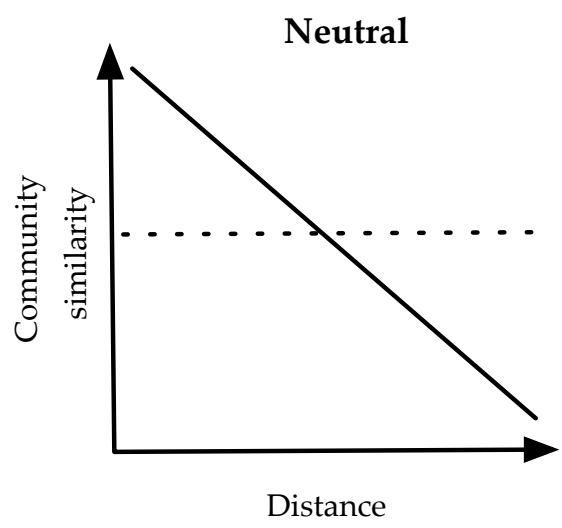

\begin{tabular}{|ll|}
\hline Geographic gradient & - \\
Environmental gradient & $\ldots .$. \\
\hline
\end{tabular}

Fig. 1. Assessing the contributions of distance and environmental effects on microbial biogeography for four metacommunity perspectives (partially redrawn from Chase et al., 2005). Patch dynamic perspective: the model predicts that species composition will not vary with environment. The relationship between species composition and geographic distance depends on assumptions that are not specified here. Species sorting perspective: predicts variation in species composition along an environmental gradient, but not along a spatial one, since all species are globally dispersed. Mass effect perspective: this model anticipates variability in species composition along with heterogeneous environmental conditions and a geographic distance gradient. Neutral perspective: the neutral model expects that species composition will vary predictably with space, but not with the environment. 
(Chase et al., 2005). Yet the relationship between species composition and geographic distance between localities is based on assumptions that have not been confirmed by specific theory and, thus, is not specified further in Fig. 1.

The species sorting perspective (Fig. 1) anticipates the presence of a multitude of heterogeneous patches (Chase et al., 2005; Holyoak et al., 2005), with community change occurring over environmental gradients or patch types. This second conceptual approach emphasises niche separation, as local environmental conditions determine community composition. Dispersal, on the other hand, is global, i.e. similarity in community structure will not depend on the distance between communities.

This second perspective is essentially the same as the 'everything is everywhere, but the environment selects' concept (Beijerinck, 1913; Baas-Becking, 1934). This cosmopolitan view focuses on the importance of local environmental characteristics as the major regulating factors for BCC and assumes that taxa are globally spread. In a rather extreme understanding of the concept, it is suggested that any ecological niche is to be occupied by one dominant taxon with a global distribution; this means that one particular type of habitat would have the same community composition anywhere on Earth.

The mass effect perspective (Fig. 1) acknowledges that environmental heterogeneity leads to differences in community composition. However, immigration into local communities causes species to be retained even in habitats where they are not favoured (Chase et al., 2005; Holyoak et al, 2005). Hence, community compositions will change along environmental gradients but will also depend on distance.

The fourth and last perspective, the neutral perspective (Fig. 1), was developed by Hubbell (2001) and presumes all species to be similar in their competitive ability as well as in movement and fitness. Probabilities of species loss (extinction, emigration) and gain (speciation, immigration) drive the spatial dynamics of species diversity. Consequently, community structures will not change over an environmental gradient but will be dependent on geographic distance (Chase et al., 2005).

The concept currently discussed the most in microbiology is probably that of species sorting. It is based on the assumption that microbial dispersal is global, because microorganisms disperse readily and are, due to extremely high abundances and rapid proliferation, unlikely to become extinct (e.g. Fenchel \& Finlay, 2004; Finlay \& Clarke, 1999). Small cell sizes and the possibility of forming resting or inactive stages (e.g. spores or cysts) lessen the importance of geographical barriers and increase the likelihood of live dispersal (Roszak \& Colwell, 1987; Fenchel et al. 1997; Finlay \& Clarke, 1999; Fenchel, 2003; Fenchel \& Finlay, 2004). Consequently, it is claimed that a high local but moderate global richness of microbial species is achieved (Fenchel, 2003).

Data supporting the species sorting view come, for instance, from studies on ciliated protozoa (Fenchel et al., 1997) and the flagellate Paraphysomonas (Finlay \& Clarke, 1999). These studies showed that a large proportion of the globally identified species within each group of organisms could be recovered in one or two study sites, indicating a global distribution. Another example supporting this perspective is the proposed global distribution of several genotypes of freshwater bacteria (Glöckner et al., 2000; Zwart et al., 2002).

However, accruing observations of spatial patterns of microbial biodiversity have lately given rise to an alternative view (e.g. Fulthorpe et al., 1998; Cho \& Tiedje, 2000; Oda et al., 2003; Papke et al., 2003; Whitaker et al., 2003; Nesbo et al., 2006). Papke et al. (2003), for example, studied island-like hot-spring cyanobacterial communities in globally distant regions (US, Japan, New Zealand and Italy), observing distinct patterns of phylogeny and a distribution of cyanobacterial genotypes consistent with geographical isolation rather than with chemical variation among the hot-springs. These examples indicate that, despite support of the species sorting perspective in microbial community compositions, other models can be equally valid. Thus, in order to describe local BCC over space and time within a conceptual framework, other views within the metacommunity concept must be evaluated as well. Studies of the importance of contemporary local habitat characteristics must therefore be accompanied by the investigation of regional factors such as geographic distance or dispersal. 


\section{Factors determining bacterioplankton diversity and biogeography in inland waters}

\section{Spatial and temporal variability}

Variation among aquatic bacterial communities occurs temporally and spatially among, as well as within, habitats. Vertical variability of BCC in stratified lakes has been shown to occur, indicating bacterioplankton niche selectivity determined by differing physicochemical conditions at different depths, for example, by differences in dissolved oxygen concentration (e.g. Urbach et al., 2001; Dominik \& Höfle, 2002; Zwisler et al., 2003). Horizontal variation of BCC has been recorded as well. However, within lakes it has been detected as being rather minor, even when looking at species or genus-like levels (Schauer et al., 2006). When horizontal variation has been revealed, it has been attributed to isolation of water by lake shoreline features, such as bays or narrow constrictions (Yannarell \& Triplett, 2004) or to sampling in close vicinity to major rivers (Dorigo et al., 2006), indicating a sensitivity of bacterioplankton distribution in lakes to hydrology. Comparisons of BCC among lakes and streams, as well as along stream and river reaches, have identified high degrees of variation (e.g. Methé \& Zehr, 1999; Dumestre et al., 2002; Muylaert et al., 2002; Sekiguchi et al., 2002; Zwart et al., 2003; Yannarell \& Triplett, 2004, 2005; Besemer et al., 2005; Crump et al., 2007; Winter et al., 2007).

Various studies have identified a seasonal development of $\mathrm{BCC}$ in rivers and lakes, with respect to both abundance and community composition, strongly indicating that seasonal factors are important in the structuring of these communities (e.g. Pernthaler et al., 1998; Höfle et al., 1999; Van der Gucht et al., 2001; Crump et al., 2003; Yannarell et al., 2003; Zwisler et al., 2003; Kent et al., 2004; Crump \& Hobbie, 2005; Schauer et al., 2006; Wu \& Hahn, 2006a; Shade et al., 2007). Whether or not lake bacteria exhibit predictable regular annual changes, such as recurring season-related abundances of specific groups or taxa, as observed for phyto- and zooplankton (Sommer et al., 1986), has yet to be fully resolved. Results, so far, have been ambiguous in this regard (summarised by Schauer et al., 2006; Wu \& Hahn, 2006a). It is evident that BCC changes over space and time, as discussed above. On an annual scale, aquatic systems do undergo fairly predictable variations in physicochemical, as well as biological, parameters. Similarly, local environmental conditions also vary over vertical and horizontal scales. Consequently, the possible connection between BCC and local habitat character has received a good deal of attention.

\section{Local factors}

Several field and experimental studies have identified numerous local factors potentially influencing BCC (Fig. 2), such as water chemistry (e.g. Methé \& Zehr, 1999; Lindström et al., 2005; Schauer et al., 2005; Yannarell \& Triplett, 2005; Wu et al., 2006), temperature (e.g. Muylaert et al., 2002; Crump \& Hobbie, 2005; Wu \& Hahn, 2006a), ultraviolet radiation (Warnecke et al., 2005), quality and quantity of dissolved organic matter (DOM) (e.g. Crump et al., 2003; Eiler et al., 2003; Kirchman et al., 2004; Kritzberg et al., 2006), primary productivity (e.g. Horner-Devine et al., 2003) and grazing (e.g. Hahn \& Höfle, 2001; Jürgens \& Matz, 2002; Pernthaler, 2005).

Grazing and DOM are probably the factors investigated most intensively amongst the environmental factors listed above. The impact of grazing comprises grazing selectivity, variation in the sensitivity of bacteria to grazing, differences in the response of bacteria to grazing, the influence of grazing on bacterial growth conditions and, finally, the influence of grazing on competition via elimination of competitors (see the thorough reviews of Hahn \& Höfle, 2001; Jürgens \& Matz, 2002; and Pernthaler, 2005). As for DOM, both quantity and quality of organic matter have been suggested, from field as well as experimental studies, to be important factors influencing the structure of bacterioplankton communities (Burkert et al., 2003; Crump et al., 2003; Eiler et al., 2003; Kritzberg et al., 2006; Pérez \& Sommaruga, 2006).

Among other local factors frequently named as important structuring forces for BCC is $\mathrm{pH}$. Several field studies have identified $\mathrm{pH}$ as co-varying strongly with 
BCC (e.g. Methé \& Zehr, 1999; Lindström et al., 2005; Schauer et al., 2005; Yannarell \& Triplett, 2005). pH may affect BCC either directly, for example by controlling the overall growth patterns of selected bacterial populations (e.g. Langenheder et al., 2006), or indirectly through the selective influence of other factors, such as the molecular structure of organic substrates (Yannarell \& Triplett, 2005).

An additional factor, though less intensively studied regarding its effect on BCC in inland waters, is salinity. Effects of salinity can be either direct (del Giorgio \& Bouvier, 2002) or indirect, caused for instance by physicochemical changes in DOC (dissolved organic carbon) composition (de Haan et al., 1987). Considering the distinction between typical groups of freshwater and marine bacterioplankton, salinity probably plays a vital role. However, the effects of salinity on BCC in inland waters have been studied far less intensively compared with their influence on BCC in coastal estuaries and solar salterns (e.g. Bouvier \& del Giorgio, 2002; Casamayor et al., 2002; del Giorgio \& Bouvier, 2002; Crump et al., 2004).

It is important to note that the local factors most frequently assessed are abiotic. Grazing, in this regard, is an exception. The importance of other biotic factors for BCC, such as virus-induced mortality and competition, have been less studied to date, yet some experimental evidence of their importance in structuring BCC does exist (e.g. Weinbauer et al., 2007).

\section{Regional factors}

As opposed to Forbes' (1887) 'The lake as a microcosm' concept, lakes are nowadays regarded as being part of larger units, i.e. their drainage areas (Soranno et al., 1999). Thus, the area or region within which a lake is situated may have an effect on the lake's local characteristics, such as $\mathrm{pH}$, salinity and DOM quantity and quality - all factors that may have profound effects on BCC, as discussed above. Such influences may hence be regarded as the effects of an indirect regional factor on the local factors, which again affect BCC (Fig. 2). Additionally, the region can influence BCC directly, for example, through the import of cells from the regional metacommunity or the limitation of dispersal within it (Fig. 2). Yet these regional processes have, in comparison to local environmental factors, been studied

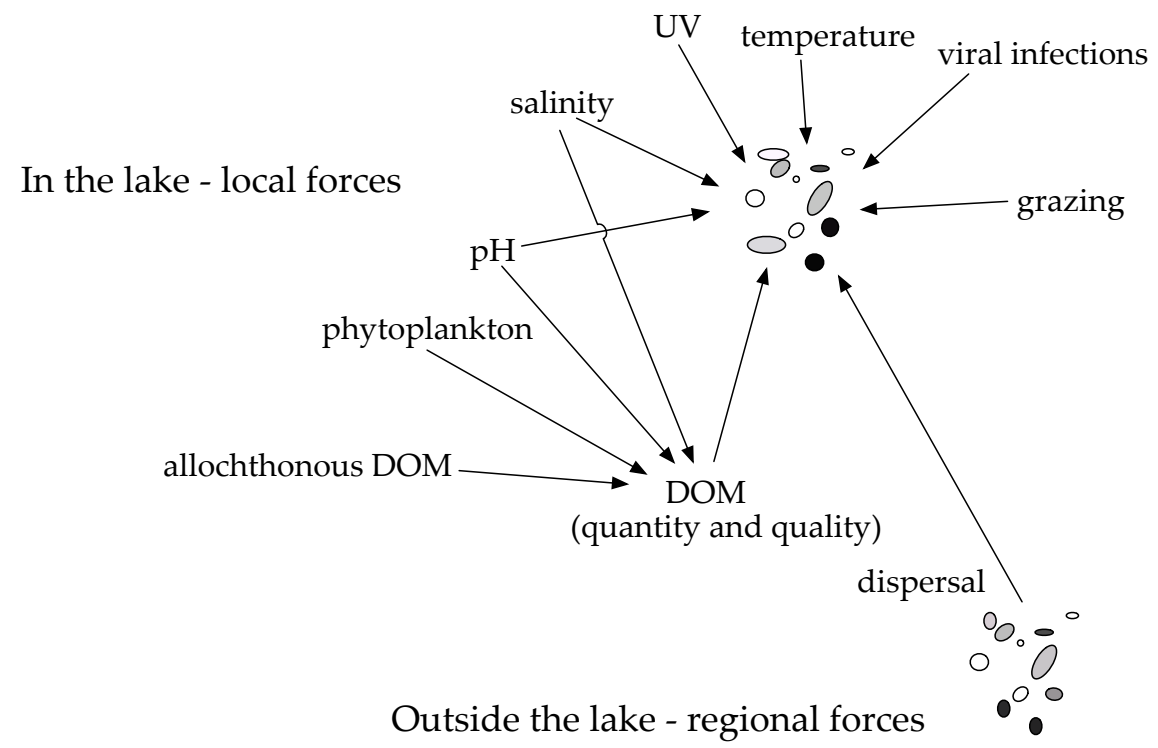

Fig. 2. Different factors potentially influencing bacterioplankton community compositions (BCC) in inland waters. DOM: dissolved organic matter. 
less frequently, especially in the context of their importance for the determination of present-day patterns in BCC. One reason for this might be that regional processes are more difficult to incorporate into ecological studies, since they act on a much larger scale, both spatially and temporally. Be that as it may, in lakes, streams and rock pools, several studies have shown that cell dispersal rate or spatial distribution can, at least to some extent, co-vary with BCC independent of local habitat character (Lindström \& Bergström, 2004, 2005; Reche et al., 2005; Lindström et al., 2006; Crump et al., 2007; Langenheder \& Ragnarsson, 2007) thereby indicating, in general, the importance of regional processes and factors.

\section{Local vs. regional factors - a conceptual} model

Only a few studies have investigated the importance of regional factors for BCC in inland waters. As a consequence, neither the relative importance of regional factors alone nor the joint effects of regional and local environmental factors on BCC in inland waters have been extensively analysed (cf. Beisner et al., 2006; Green \& Bohannan, 2006). Several studies have detected signatures of regional factors on BCC (as discussed above). Beisner et al. (2006) and Van der Gucht et al. (2007), however, identified a stronger correlation between local environmental factors and BCC than between spatial distribution of lakes and BCC. By contrast, Langenheder \& Ragnarsson (2007) found both regional factors and local environment to be significant in a set of coastal rock pools. Hence, the relative strengths of correlations between BCC and regional forces on one hand and local environmental conditions on the other appear to differ between study objects.

It is important to point out that the very correlation between BCC and the spatial distribution of lakes is no proof whatsoever for a greater importance of direct regional processes over local factors for BCC. For example, nearby localities can be more similar in local character (such as water chemistry) than distant ones and, thus, select for similar taxa. The difficulty of co-varying space and habitat characters can, to some extent, be untangled by multivariate analysis (e.g. Beisner et al., 2006; Langenheder \& Ragnarsson, 2007; Van der Gucht et al., 2007), but an experimental approach might also be desirable.

In a set of experiments, Langenheder et al. $(2005,2006)$ attempted to determine whether local or regional processes were of greater importance to BCC at the local scale. The inoculation of bacteria from different sources (lakes, streams and groundwater) into identical environmental conditions produced distinct bacterial communities, indicating that the history and distribution of taxa within the source community (inoculum) were fundamental to shaping the new BCC. Local environmental conditions (the medium), on the other hand, seemed to be less important. In contrast, Kirchman et al. (2004) obtained opposite results in an experiment with bacteria from the Hudson River. Since even experimental approaches are not consistent in their conclusions as to whether local or regional factors are more important in shaping BCC in inland waters, it appears that different factors are important under different circumstances. Therefore, in order to understand how BCC in inland waters is regulated, it is important to consider the localities where, and circumstances under which, particular types of factors could exert a greater or lesser influence.

In a field study of 12 lakes, Lindström et al. (2006) found that BCC in lakes of short water retention time ${ }^{1}$ appeared to be determined by cell import from the drainage area, while in lakes of longer water retention time BCC seemed to be shaped more by factors within the lakes. Thus, depending on whether lakes have short (< 100 days; Lindström et al., 2006) or long ( $>700$ days; e.g. Beisner et al., 2006) retention times, the relative importance of local versus regional factors, i.e. that of mass effect versus species sorting, may differ. Likewise, in a study including lakes as well as streams, Crump et al. (2007) concluded that stream BCC could be determined by mass effect, while cell dispersal into the studied lakes was considered to be too low to generate a mass effect as a consequence of the longer water retention times.

${ }^{1}$ Defined as the average time for a packet of water to pass through a lake, from entering it to leaving it. It is usually calculated as: $\mathrm{T}=$ lake volume/volume of inflowing water per time unit. 


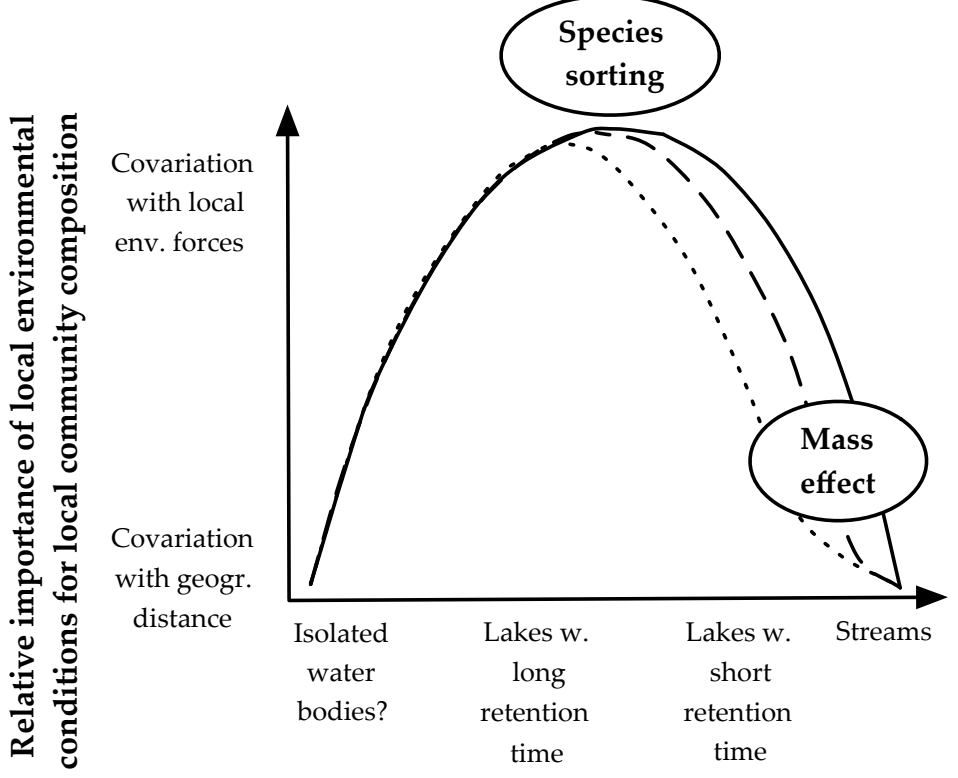

Cell influx rate
Fig. 3. Conceptual figure describing the possible relative importance of local environmental conditions for local bacterioplankton community composition (BCC) in inland waters, depending on cell influx rate of the locality. Different scenarios are expected depending on functional plasticity of taxa within the metacommunity and/or the cell growth rates. The figure also shows under which circumstances species sorting or mass effect could apply. The scenario in the lower left corner corresponds to dispersal limitation. It still remains to be shown if inland water bodies isolated to the extent of dispersal limitation do exist. is not enough to overshadow the influence of indigenous local habitat character. Therefore, the species sorting perspective (i.e. 'everything is everywhere but the environment selects') well describes the BCC dynamics (Fig. 3). Hence, in lakes of such nature, local BCC and local environmental factors will co-vary to a greater extent (Figs 1 \& 3).

Our conceptual model thus claims that different processes and different concepts are applicable under differing dispersal regimes (Fig. 3). The vital questions to be asked in this regard are 'Where does the discriminating point lie that distinguishes between externallyand internally-controlled lakes, i.e. between lakes regulated by masseffect and species-sorting?' and 'What are the characteristics that determine this discrimination point?'. In considering data from oligotrophic lakes, Lindström et al. (2006) suggested a critical point of discrimination at a water retention time of 100-200 days. This point, however, need not be the same for all systems. For instance, we
Based on these ideas and invoking metacommunity theory, we propose a conceptual model for BCC in inland waters (Fig. 3). The model allows a relationship between the relative importance of local environmental factors for local BCC and the system's exchange rate of bacterial cells (which should correspond to water exchange rate, i.e. water retention time). Thus, we assume that BCC in rivers and in lakes of short water retention times is influenced most by mass effects, through the input of bacteria, and less by local environmental factors (Fig. 3). In contrast, the rate of cell import from the drainage area to lakes having longer water retention times allows global dispersal but acknowledge that in systems of high growth rates, such as eutrophic lakes, a greater input of cells (i.e. a shorter water retention time) might be needed to overrule the internal production of cells and cause a mass effect, i.e. in such systems species sorting might be more pronounced (Fig. 3). Accordingly, the results from a study of 98 relatively eutrophic lakes indicated an overwhelming importance of species sorting for BCC as opposed to mass effect (Van der Gucht et al., 2007). Whether different discrimination points between mass effect and species sorting for productive and unproductive waters do exist, however, needs to be confirmed in future research. 
Crump etal. (2004) identified a different discrimination point at a water retention time of just a few days for an estuary, which might support the greater importance of species sorting in productive waters, even when cell import rates are high. This finding, however, might also be due to the fact that an estuary presents a more stressful environment to bacteria being washed into the estuary from rivers and streams of lower salinity, compared to bacteria being washed into a freshwater lake. Hence, depending on the capability of an imported cell to establish itself in a new environment, the importance of mass effect or that of species sorting could vary. Functional plasticity of bacterial cells within the metacommunity, therefore, may also affect which factors and processes are acting on BCC (Fig. 3). For example, if functional plasticity is low, i.e. the bacteria in a certain metacommunity only thrive in a very narrow range of environments, then the significance of local habitat characteristics for BCC may be high and the bacterial assemblage best be described by the species sorting perspective (Fig. 3). At the other extreme, if bacteria are characterised by high plasticity they may be able to establish themselves in many environments of different types and, therefore, the impact of local environmental factors might be negligible, and mass effect is accordingly more likely.

In the very extreme case where bacterioplankton species are very plastic and can readily grow in virtually any kind of inland water, no differences in competitive ability will exist and local environmental factors become unimportant. If so, the neutral (and possibly patch dynamics) perspective should best describe the bacterial assemblage dynamics. Several typical freshwater bacterial groups seem to be characterised by a high ecological plasticity, i.e. thriving in a wide variety of inland waters (Hahn, 2006). However, more research is required to elucidate the plasticity/niche concept for bacterioplankton species. Some support of the neutral model is given by results from a study of 96 lakes conducted by Sloan et al. (2006). The observed abundances and frequencies of freshwater bacterial groups in these lakes followed a pattern predicted by a neutral model.

Another question yet to be answered is whether BCC in inland waters could be influenced by limitation of cell dispersal as a consequence of geographical isolation on a local or aglobal scale. In suchinstances, it would beexpected that $\mathrm{BCC}$ would be uncoupled from species sorting because dispersal rates are low and the pool of species from which to sort is diminished. Thus, an organism could thrive in a suboptimal environment because potentially superior competitors have not yet arrived at the particular habitat. In these cases, there would also be a co-variation between the distances separating communities and differences in BCC. However, BCC and environmental characters should co-vary to a lesser extent as visualised in the lower left corner of Fig. 3. According to Martiny et al. (2006), dispersal limitation could occur in microbial communities, although such a mechanism seems unlikely to apply to most lakes and rivers as such localities are connected, not just hydrologically but also aerially. The notion of globally distributed freshwater taxa (Glöckner et al., 2000; Zwart et al., 2002), as well as results from BCC estimates in 98 European lakes, also contradicts this idea (Van der Gucht et al., 2007). However, permanently ice-covered lakes (Priscu et al., 1999) and isolated pockets of groundwater could potentially receive little input of dispersed cells from surrounding communities and, hence, could potentially be subject to dispersal limitation (Fig. 3). This, however, has yet to be shown and might be an exception rather than a rule.

\section{Challenges for the future}

Future challenges for microbial biogeography research include the formulation of concepts and hypotheses as well as their adequate testing. We have already mentioned that studies testing the relative importance of local environmental versus regional forces are lacking. In order to test the predictions from our conceptual model, future studies need to be conducted in a systematic way. For instance, BCC in sets of lakes of differing productivity and water retention times could be investigated, followed by multivariate analyses (e.g. Beisner et al., 2006; Langenheder \& Ragnarsson, 2007; Van der Gucht et al., 2007). Using a similar approach, it would be of great interest to verify whether BCC is shaped by different mechanisms during different seasons, due to, for instance, variations in water 
flow regimes and growth rates (e.g. as a consequence of differing temperatures). Further, estimates of cell dispersal rates in the field, via air and waterways, coupled with analyses of BCC are extremely rare. In order to test explicitly whether dispersal limitation and mass effects can occur, such estimates must be made and related to rates of other processes possibly influencing BCC (i.e. growth rate, mortality rate, speciation, extinction).

One complicating fact in the interpretation of field data is that different taxa of bacterioplankton in one single community might differ in their functional plasticity and the ease of their live dispersal. All populations are treated equally in field surveys and subsequent statistical analyses, although it is possible that different populations are differentially prone to mass effect, species sorting or dispersal limitation. Therefore, clear statistical relationships between BCC and environment or cell dispersal, for instance, might not be achieved. Tracking individual populations or dividing datasets into subsets might circumvent this problem and could provide us with information about the occurrence of specialists and generalists.

Another complicating issue in field studies is that spatial and dispersal factors often co-vary with local environmental factors, making the two types of forces difficult to distinguish. It is obvious that although field studies are a necessity in biogeography research, we expect that experimental approaches can be developed further to test specific hypotheses. For instance, the estimation of immigrating capabilities of bacterioplankton, air-borne, and soil bacteria under differing circumstances (cell growth rates, immigration rates) should be a rather fruitful approach to test, for example, under which circumstances the various concepts within our model (Fig. 3) might apply.

Concerning the outline of future research, we have to ask ourselves how big is the gap in available data regarding the distribution of bacterioplankton species over space and time, and what consequences for the comprehension of bacterial biogeography in inland waters arise from this gap in knowledge. A literature search in this regard (Fig. 4, see figure legend for details) shows that:

1. The vast majority of studies on BCC in inland waters have been conducted in lakes, ponds and reservoirs, with fewer surveys done in rivers and streams, and that,

2. Most studies have been carried out in Europe and North America.

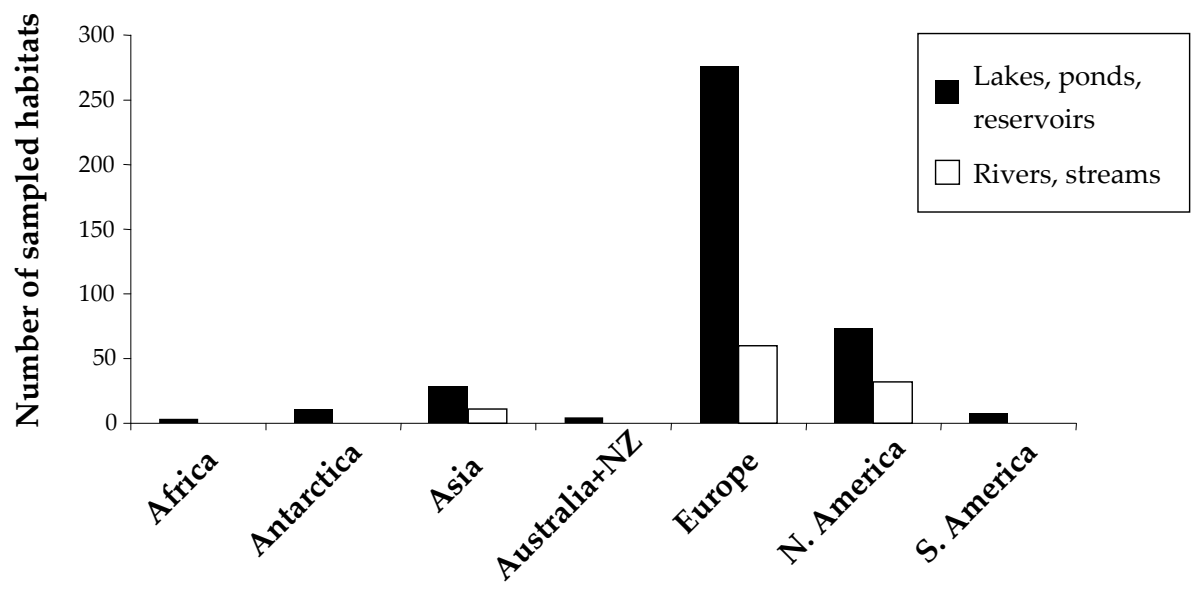

Fig. 4. Results from a literature search in ISI Web of Science, 19 June 2007. It shows the number of habitats on different continents where some kind of molecular method was applied to characterise, at least partially, the bacterioplankton community composition. The search term applied was bacterioplankton AND (lake OR pond OR reservoir OR freshwater OR river OR stream OR groundwater) AND (diversity OR structure OR composition). Papers dealing with sediments or biofilms, hot springs and cultivated bacteria (isolates or mixed cultures) were removed. Lakes were identified by name and country to avoid repeated counting of the same lakes being investigated in several studies. 'North America' comprises Canada, USA and Mexico. 'Europe' also includes the European part of Russia. NZ=New Zealand. 
Moreover, considering that the number of study sites in even the most frequently sampled countries is low, all continents are severely understudied with some sampled hardly at all. This applies to lakes but to an even greater extent to streams and rivers, which are strikingly undersampled.

Consequently, considering the possibility that (2) might apply, any statements of global distribution of bacterial taxa (Glöckner et al., 2000; Zwart et al., 2002) must be considered as tentative. Regarding the former finding (1) and following Crump et al.'s (2007) argument that soil bacteria are an integral component of headwater streams, it could be concluded that our view of what is a typical freshwater bacterium (Zwart et al., 2002) might be affected by an undersampling of riverine communities. Finally, according to our conceptual model (Fig. 3), an undersampling of localities characterised by short water retention times or isolated localities could affect our conclusions about the relative importance of mass effect and dispersal limitation, respectively, for BCC in inland waters in general.

The data available may also affect our view of bacterial biogeography in other ways, i.e. depending on the choice of sampling or analysis strategy. For instance, it has been suggested that the disparate outcomes regarding recurrent seasonality of lake bacterioplankton communities could be a result of differences in the taxonomic resolution of the method applied (Schauer et al., 2006; Wu \& Hahn, 2006a). A finer resolution should increase the possibility to detect variation and, thus, recurrent patterns should be less likely (Schauer et al., 2006; Wu \& Hahn, 2006a).

The subject of taxonomic scaling is most frequently discussed in the light of an increasing taxonomic resolution (e.g. Green \& Bohannan, 2006). The need to do so can be shown, for example, by the findings of niche differentiation among identified freshwater clusters within major groups, such as the $\beta$-Proteobacteria and Actinobacteria (Zwart et al., 2003; Lindström et al., 2005; Schauer et al., 2005; Wu \& Hahn, 2006b; Wu et al., 2006). Yet it is unclear which taxonomic resolution provides meaningful ecological information and when we are merely measuring noise, reflecting mutations with no functional consequences. In any case, the number of studies combining different approaches and, thus, different levels of resolution is rather low (Green \& Bohannan, 2006). A fairly rare example in this respect is a study of bacterial communities in river sediments undertaken by Kloep et al. (2006), who found different spatial patterns depending on the phylogenetic level of the applied probes. Although similar results for bacterioplankton, to our knowledge, remain to be shown, taxonomic resolution might be a matter of concern depending on the question posed and could, furthermore, have an impact on the biogeographical patterns observed.

\section{Conclusions}

Important insight into the community structure and the spatial and temporal scaling of bacterial diversity has been gained; bacterial diversity might indeed exhibit explicable spatial and temporal patterns reminiscent of those observed among animals and plants. Major challenges for the future will be the comprehension of the underlying mechanisms of bacterial diversity and biogeography. Factors determining and maintaining microbial diversity and biogeography need to be further elucidated. Furthermore, there is a need to improve our understanding of the potential importance of regional factors for local BCC, such as cell dispersal, as they are less frequently analysed in contrast to local environmental factors. The use of theoretical frameworks, such as the metacommunity concept, may facilitate such studies. Other challenges to be met include the application of appropriate taxonomic scales.

Finally, it is important to keep in mind that the study of bacterial diversity is a young science and that the data available are considerably limited and, thus, likely to affect our conceptual understanding of bacterioplankton biogeography. At the same time, it has been suggested that bacterial species could be used as model organisms. Their small body size and short generation time renders them ideal for study over several spatial and temporal scales simultaneously; an eminent advantage over macroorganisms (Jessup et al., 2004). Moreover, dispersal rates of lake bacteria to and between lakes may be fairly simple to quantify via water-flow rate measurements when compared to the dispersal rates of macroorganisms. 
This, of course, requires that cell dispersal rates via air, rain, groundwater and from sediments are negligible compared to dispersal via surface runoff, a prerequisite that could depend on lake type and has yet to be confirmed. For these reasons, we argue in favour of the use of lake bacterioplankton as model organisms in metacommunity research; studies of bacterioplankton diversity and biogeography in inland waters should therefore continue and be promoted.

\section{Acknowledgements}

We would like to express our gratitude to Stina Drakare, Silke Langenheder, Lars Tranvik, Luc de Meester and an anonymous reviewer for critical but helpful inputs on earlier versions of the manuscript. Further thanks are given to Örjan Östman for stimulating discussions on the concept of metacommunities.

\section{References}

Baas-Becking, L.G.M. (1934). Geobiologie of inleiding tot de milieukunde. W.P. Van Stockum \& Zoon, The Hague, The Netherlands.

Beijerinck, M.W. (1913). De infusies en de ontdekking der backteriën. Jaarboek van de Koninklijke Aakademie voor Wetenschappen. Müller. Amsterdam, The Netherlands.

Beisner, B.E., Peres-Neto, P.R., Lindström, E.S., Barnett, A. \& Longhi, M.L. (2006). The role of environmental and spatial processes in structuring lake communities from bacteria to fish. Ecology 87, 2985-2991.

Besemer, K., Moeseneder, M.M., Arrieta, J.M., Herndl, G.J. \& Peduzzi, P. (2005). Complexity of bacterial communities in a river-floodplain system (Danube, Austria). Applied and Environmental Microbiology 71, 609-620.

Bouvier, T.C. \& del Giorgio, P.A. (2002). Compositional changes in free-living bacterial communities along a salinity gradient in two temperate estuaries. Limnology and Oceanography 47, 453470.

Burkert, U., Warnecke, F., Babenzien, D., Zwirnmann, E. \& Pernthaler, J. (2003). Members of a readily enriched $\beta$ proteobacterial clade are common in surface waters of a humic lake. Applied and Environmental Microbiology 69, 6550-6559.
Casamayor, E.O., Massana, R., Benlloch, S., Øvreås, L., Díez, B., Goddard, V.J., Gasol, J.M., Joint, I., Rodríguez-Valera, F. \& Pedrós-Alió, C. (2002). Changes in archaeal, bacterial and eukaryal assemblages along a salinity gradient by comparison of genetic fingerprinting methods in a multipond solar saltern. Environmental Microbiology 4, 338-348.

Chase, J.M., Amarasekare, P., Cottenie, K., Gonzalez, A., Holt, R.D., Holyoak, M., Hoopes, M.F., Leibold, M.A., Loreau, M., Mouquet, N.M., Shurin, J.B. \& Tilman, D. (2005). Competing theories for competitive metacommunities. In: Metacommunities: Spatial Dynamics and Ecological Communities (eds M. Holyoak, M.A. Leibold \& R.D. Holt), pp. 335-354. The University of Chicago Press, Chicago and London.

Cho, J.-C. \& Tiedje, J.M. (2000). Biogeography and degree of endemicity of fluorescent Pseudomonas in soil. Applied and Environmental Microbiology 66, 5448-5456.

Crump, B.C. \& Hobbie, J.E. (2005). Synchrony and seasonality in bacterioplankton communities of two temperate rivers. Limnology and Oceanography 50, 1718-1729.

Crump, B.C., Kling, G.W., Bahr, M. \& Hobbie, J.E. (2003). Bacterioplankton community shifts in an Arctic lake correlate with seasonal changes in organic matter source. Applied and Environmental Microbiology 69, 2253-2268.

Crump, B.C., Hopkinson, C.S., Sogin, M.L. \& Hobbie, J.E. (2004). Microbial biogeography along an estuarine salinity gradient: combined influences of bacterial growth and residence time. Applied and Environmental Microbiology 70, 1494-1505.

Crump, B.C., Adams, H.E., Hobbie, J.E. \& Kling, G.W. (2007). Biogeography of bacterioplankton in lakes and streams of an arctic tundra catchment. Ecology 88, 1365-1378.

Curtis, T.P., Sloan, W.T. \& Scannell, J.W. (2002). Estimating prokaryotic diversity and its limits. Proceedings of the National Academy of Sciences of the United States of America 99, 1049410499.

de Haan, H., Jones, R.I. \& Salonen, K. (1987). Does ionic strength affect the configuration of aquatic humic substances, as indicated by gel filtration? Freshwater Biology 17, 453-459.

del Giorgio, P.A. \& Bouvier, T.C. (2002). Linking the physiologic and phylogenetic successions in free-living bacterial communities along an estuarine salinity gradient. Limnology and Oceanography 47, 471-486.

Dominik, K. \& Höfle, M.G. (2002). Changes in bacterioplankton 
community structure and activity with depth in a eutrophic lake as revealed by 5 S rRNA analysis. Applied and Environmental Microbiology 68, 3606-3613.

Dorigo, U., Fontvieille, D. \& Humbert, J.-F. (2006). Spatial variability in the abundance and composition of the free-living bacterioplankton community in the pelagic zone of Lake Bourget (France). FEMS Microbiology Ecology 58, 109-119.

Dumestre, J.-F., Casamayor, E.O., Massana, R. \& Pedrós-Alió, C. (2002). Changes in bacterial and archaeal assemblages in an equatorial river induced by the water eutrophication of Petit Saut dam reservoir (French Guiana). Aquatic Microbial Ecology 26, 209-221.

Eiler, A., Langenheder, S., Bertilsson, S. \& Tranvik, L.J. (2003). Heterotrophic bacterial growth efficiency and community structure at different natural organic carbon concentrations. Applied and Environmental Microbiology 69, 3701-3709.

Fenchel, T. (2003). Biogeography for bacteria. Science 301, 925926.

Fenchel, T. \& Finlay, B.J. (2004). The ubiquity of small species: Patterns of local and global diversity. Bioscience 54, 777-784.

Fenchel, T., Esteban, G.F. \& Finlay, B.J. (1997). Local versus global diversity of microorganisms: cryptic diversity of ciliated protozoa. Oikos 80, 220-225.

Finlay, B.J. \& Clarke, K.J. (1999). Ubiquitous dispersal of microbial species. Nature $400,828$.

Forbes, S.A. (1887). The lake as a microcosm. Bulletin Science Association of Peoria, Illinois. 1887, 77-87.

Forney, L.J., Zhou, X. \& Brown, C.J. (2004). Molecular microbial ecology: land of the one-eyed king. Current Opinion in Microbiology 7, 210-220.

Fulthorpe, R.R., Rhodes, A.N. \& Tiedje, J.M. (1998). High levels of endemicity of 3-chlorobenzoate-degrading soil bacteria. Applied and Environmental Microbiology 64, 1620-1627.

Giovannoni, S.J., Britschgi, T.B., Moyer, C.L. \& Field, K.G. (1990). Genetic diversity in Sargasso Sea bacterioplankton. Nature 345, 60-63.

Glöckner, F.O., Zaichikov, E., Belkova, N., Denissova, L., Pernthaler, J., Pernthaler, A. \& Amann, R. (2000). Comparative $16 \mathrm{~S}$ rRNA analysis of lake bacterioplankton reveals globally distributed phylogenetic clusters including an abundant group of Actinobacteria. Applied and Environmental Microbiology 66, 5053-5065.
Green, J. \& Bohannan, B.J.M. (2006). Spatial scaling of microbial biodiversity. Trends in Ecology and Evolution 21, 501-507.

Hahn, M.W. (2006). The microbial diversity of inland waters. Current Opinion in Biotechnology 17, 256-261.

Hahn, M.W. \& Höfle, M.G. (2001). Grazing of protozoa and its effect on populations of aquatic bacteria. FEMS Microbiology Ecology 35, 113-121.

Hanski, I. \& Gilpin, M. (1991). Metapopulation dynamics - brief history and conceptual domain. Biological Journal of the Linnean Society 42, 3-16.

Höfle, M.G., Haas, H. \& Dominik, K. (1999). Seasonal dynamics of bacterioplankton community structure in a eutrophic lake as determined by $5 \mathrm{~S}$ rRNA analysis. Applied and Environmental Microbiology 65, 3164-3174.

Holyoak, M., Leibold, M.A., Mouquet, N.M., Holt, R.D. \& Hoopes, M.F. (2005). Metacommunities: a framework for large-scale community ecology. In: Metacommunities: Spatial Dynamics and Ecological Communities (eds M. Holyoak, M.A. Leibold \& R.D. Holt), pp. 1-31. The University of Chicago Press, Chicago and London.

Horner-Devine, M.C., Leibold, M.A., Smith, V.H. \& Bohannan, B.J.M. (2003). Bacterial diversity patterns along a gradient of primary productivity. Ecology Letters 6, 613-622.

Horner-Devine, M.C., Silver, J.M., Leibold, M.A., Bohannan, B.J.M., Colwell, R.K., Fuhrman, J.A., Green, J.L., Kuske, C.R., Martiny, J.B.H., Muyzer, G., Øvreås, L., Reysenbach, A.-L. \& Smith, V.H. (2007). A comparison of taxon co-occurrence patterns for macro- and microorganisms. Ecology 88, 1345-1353.

Hubbell, S.P. (2001). The Unified Neutral Theory of Biodiversity and Biogeography. Princeton University Press, Princeton, NJ.

Jessup, C.M., Kassen, R., Forde, S.E., Kerr, B., Buckling, A., Rainey, P.B. \& Bohannan, B.J.M. (2004). Big questions, small worlds: microbial model systems in ecology. Trends in Ecology and Evolution 19, 189-197.

Jürgens, K. \& Matz, C. (2002). Predation as a shaping force for the phenotypic and genotypic composition of planktonic bacteria. Antonie van Leeuwenhoek 81, 413-434.

Kent, A.D., Jones, S.E., Yannarell, A.C., Graham, J.M., Lauster, G.H., Kratz, T.K. \& Triplett, E.W. (2004). Annual patterns in bacterioplankton community variability in a humic lake. Microbial Ecology 48, 550-560.

Kirchman, D.L., Dittel, A.I., Findlay, S.E.G. \& Fischer, D. (2004). 
Changes in bacterial activity and community structure in response to dissolved organic matter in the Hudson River, New York. Aquatic Microbial Ecology 35, 243-257.

Kloep, F., Manz, W. \& Röske, I. (2006). Multivariate analysis of microbial communities in the River Elbe (Germany) on different phylogenetic and spatial levels of resolution. FEMS Microbiology Ecology 56, 79-94.

Kritzberg, E.S., Langenheder, S. \& Lindström, E.S. (2006). Influence of dissolved organic matter source on lake bacterioplankton structure and function - implications for seasonal dynamics of community composition. FEMS Microbiology Ecology 56, 406417.

Langenheder, S. \& Ragnarsson, H. (2007). The role of environmental and spatial factors for the composition of aquatic bacterial communities. Ecology 88, 2154-2161.

Langenheder, S., Lindström, E.S. \& Tranvik, L.J. (2005). Weak coupling between community composition and functioning of aquatic bacteria. Limnology and Oceanography 50, 957-967.

Langenheder, S., Lindström, E.S. \& Tranvik, L.J. (2006). Structure and function of bacterial communities emerging from different sources under identical conditions. Applied and Environmental Microbiology 72, 212-220.

Leibold, M.A., Holyoak, M., Mouquet, N., Amarasekare, P., Chase, J.M., Hoopes, M.F., Holt, R.D., Shurin, J.B., Law, R., Tilman, D., Loreau, M. \& Gonzalez, A. (2004). The metacommunity concept: a framework for multi-scale community ecology. Ecology Letters 7, 601-613.

Lindström, E.S. \& Bergström, A.-K. (2004). Influence of inlet bacteria on bacterioplankton assemblage composition in lakes of different hydraulic retention time. Limnology and Oceanography 49, $125-136$.

Lindström, E.S. \& Bergström, A.-K. (2005). Community composition of bacterioplankton and cell transport in lakes in two different drainage areas. Aquatic Sciences 67, 210-219.

Lindström, E.S., Kamst-van Agterveld, M.P. \& Zwart, G. (2005). Distribution of typical freshwater bacterial groups is associated with $\mathrm{pH}$, temperature and lake water retention time. Applied and Environmental Microbiology 71, 8201-8206.

Lindström, E.S., Forslund, M., Algesten, G. \& Bergström, A.-K. (2006). External control of bacterial community structure in lakes. Limnology and Oceanography 51, 339-342.

Martiny, J.B.H., Bohannan, B.J.M., Brown, J.H., Colwell, R.K.,
Fuhrman, J.A., Green, J.L., Horner-Devine, M.C., Kane, M., Krumins, J.A., Kuske, C.R., Morin, P.J., Naeem, S., Øvreås, L., Reysenbach, A.-L., Smith, V.H. \& Staley, J.T. (2006). Microbial biogeography: putting microorganisms on the map. Nature Reviews Microbiology 4, 102-112.

Methé, B.A. \& Zehr, J.P. (1999). Diversity of bacterial communities in Adirondack lakes: do species assemblages reflect lake water chemistry? Hydrobiologia 401, 77-96.

Morris, R.M., Rappé, M.S., Connon, S.A., Vergin, K.L., Siebold, W.A., Carlson, C.A. \& Giovannoni, S.J. (2002). SAR11 clade dominates ocean surface bacterioplankton communities. Nature 420, 806-810.

Muylaert, K., Van der Gucht, K., Vloemans, N., De Meester, L., Gillis, M. \& Vyverman, W. (2002). Relationship between bacterial community composition and bottom-up versus topdown variables in four eutrophic shallow lakes. Applied and Environmental Microbiology 68, 4740-4750.

Nesbo, C.L., Dlutek, M. \& Doolittle, W.F. (2006). Recombination in Thermotoga: implications for species concepts and biogeography. Genetics 172, 759-769.

Nocker, A., Burr, M. \& Camper, A.K. (2007). Genotypic microbial community profiling: a critical technical review. Microbial Ecology 54, 276-289.

Oda, Y., Star, B., Huisman, L.A., Gottschal, J.C. \& Forney, L.J. (2003). Biogeography of the purple nonsulfur bacterium Rhodopseudomonas palustris. Applied and Environmental Microbiology 69, 5186-5191.

Papke, R.T., Ramsing, N.B., Bateson, M.M. \& Ward, D.M. (2003). Geographical isolation in hot spring cyanobacteria. Environmental Microbiology 5, 650-659.

Pérez, M.T. \& Sommaruga, R. (2006). Differential effect of algaland soil-derived dissolved organic matter on alpine lake bacterial community composition and activity. Limnology and Oceanography 51, 2527-2537.

Pernthaler, J. (2005). Predation on prokaryotes in the water column and its ecological implications. Nature Reviews Microbiology 3, 537-546.

Pernthaler, J., Glöckner, F.-O., Unterholzner, S., Alfreider, A., Psenner, R. \& Amann, R. (1998). Seasonal community and population dynamics of pelagic bacteria and archaea in a high mountain lake. Applied and Environmental Microbiology 64, 42994306. 
Priscu, J.C., Adams, E.E., Lyons, W.B., Voytek, M.A., Mogk, D.W., Brown, R.L., McKay, C.P., Takacs, C.D., Welch, K.A., Wolf, C.F., Kirshtein, J.D. \& Avci, R. (1999). Geomicrobiology of subglacial ice above Lake Vostok, Antarctica. Science 286, 2141-2144.

Prosser, J.I., Bohannan, B.J.M., Curtis, T.P., Ellis, R.J., Firestone, M.K., Freckleton, R.P., Green, J.L., Green, L.E., Killham, K., Lennon, J.J., Osborn, A.M., Solan, M., van der Gast, C.J. \& Young, J.P.W. (2007). The role of ecological theory in microbial ecology. Nature Reviews Microbiology 5, 384-392.

Reche, I., Pulido-Villena, E., Morales-Baquero, R. \& Casamayor, E.O. (2005). Does ecosystem size determine aquatic bacterial richness? Ecology 86, 1715-1722.

Roszak, D.B. \& Colwell, R.R. (1987). Survival strategies of bacteria in the natural environment. Microbiological Reviews 51, 365-379.

Schauer, M., Kamenik, C. \& Hahn, M.W. (2005). Ecological differentiation within a cosmopolitan group of planktonic freshwater bacteria (SOL Cluster, Saprospiraceae, Bacteroidetes). Applied and Environmental Microbiology 71, 5900-5907.

Schauer, M., Jiang, J. \& Hahn, M.W. (2006). Recurrent seasonal variations in abundance and composition of filamentous SOL cluster bacteria (Saprospiraceae, Bacteroidetes) in oligomesotrophic Lake Mondsee(Austria). Applied and Environmental Microbiology $72,4704-4712$

Sekiguchi, H., Watanabe, M., Nakahara, T., Xu, B. \& Uchiyama, H. (2002). Succession of bacterial community structure along the Changiiang river determined by denaturing gradient gel electrophoresis and clone library analysis. Applied and Environmental Microbiology 68, 5142-5150.

Selje, N., Simon, M. \& Brinkhoff, T. (2004). A newly discovered Roseobacter cluster in temperate and polar oceans. Nature 427, 445-448.

Shade, A., Kent, A.D., Jones, S.E., Newton, R.J., Triplett, E.W. \& McMahon, K.D. (2007). Interannual dynamics and phenology of bacterial communities in a eutrophic lake. Limnology and Oceanography 52, 487-494.

Sloan, W.T., Lunn, M., Woodcock, S., Head, I.M., Nee, S. \& Curtis, T.P. (2006). Quantifying the roles of immigration and chance in shaping prokaryote community structure. Environmental Microbiology 8, 732-740.

Sommer, U., Gliwicz, Z.M., Lampert, W. \& Duncan, A. (1986). The PEG-model of seasonal succession of planktonic events in fresh waters. Archiv für Hydrobiologie 106, 433-471.
Soranno, P.A., Webster, K.E., Riera, J.L., Kratz, T.K., Baron, J.S., Bukaveckas, P.A., Kling, G.W., White, D.S., Caine, N., Lathrop, R.C. \& Leavitt, P.R. (1999). Spatial variation among lakes within landscapes: ecological organization along lake chains. Ecosystems 2, 395-410.

Urbach, E., Vergin, K.L., Young, L., Morse, A., Larson, G.L. \& Giovannoni, S.J. (2001). Unusual bacterioplankton community structure in ultra-oligotrophic Crater Lake. Limnology and Oceanography 46, 557-572.

Van der Gucht, K., Sabbe, K., De Meester, L., Vloemans, N., Zwart, G., Gillis, M. \& Vyverman, W. (2001). Contrasting bacterioplankton community composition and seasonal dynamics in two neighbouring hypertrophic freshwater lakes. Environmental Microbiology 3, 680-690.

Van der Gucht, K., Cottenie, K., Muylaert, K., Vloemans, N., Cousin, S., Declerck, S., Jeppesen, E., Conde-Porcuna, J.-M., Schwenk, K., Zwart, G., Degans, H., Vyverman, W. \& De Meester, L. (2007). The power of species sorting: local factors drive bacterial community composition over a wide range of spatial scales. Proceedings of the National Academy of Sciences of the United States of America 51, 20404-20409.

Warnecke, F., Sommaruga, R., Sekar, R., Hofer, J.S. \& Pernthaler, J. (2005). Abundances, identity, and growth state of Actinobacteria in mountain lakes of different UV transparency. Applied and Environmental Microbiology 71, 5551-5559.

Weinbauer, M.G., Hornák, K., Jezbera, J., Nedoma, J., Dolan, J.R. \& Simek, K. (2007). Synergistic and antagonistic effects of viral lysis and protistan grazing on bacterial biomass, production, and diversity. Environmental Microbiology 9, 777-788.

Whitaker, R.J., Grogan, D.W. \& Taylor, J.W. (2003). Geographic barriers isolate endemic populations of hyperthermophilic archaea. Science 301, 976-978.

Winter, C., Hein, T., Kavka, G., Mach, R.L. \& Farnleitner, A.H. (2007). Longitudinal changes in the bacterial community composition of the Danube River: a whole-river approach. Applied and Environmental Microbiology 73, 421-431.

Wu, Q.L. \& Hahn, M.W. (2006a). High predictability of the seasonal dynamics of a species-like Polynucleobacter population in a freshwater lake. Environmental Microbiology 8, 1660-1666.

Wu, Q.L. \& Hahn, M.W. (2006b). Differences in structure and dynamics of Polynucleobacter communities in a temperate and a subtropical lake, revealed at three phylogenetic levels. FEMS 
Microbiology Ecology 57, 67-79.

Wu, Q.L., Zwart, G., Schauer, M., Kamst-van Agterveld, M.P. \& Hahn, M.W. (2006). Bacterioplankton community composition along a salinity gradient of sixteen high-mountain lakes located on the Tibetan Plateau, China. Applied and Environmental Microbiology 72, 5478-5485.

Yannarell, A.C. \& Triplett, E.W. (2004). Within- and between-lake variability in the composition of bacterioplankton communities: investigations using multiple spatial scales. Applied and Environmental Microbiology 70, 214-223.

Yannarell, A.C. \& Triplett, E.W. (2005). Geographic and environmental sources of variation in lake bacterial community composition. Applied and Environmental Microbiology 71, 227239.

Yannarell, A.C., Kent, A.D., Lauster, G.H., Kratz, T.K. \& Triplett, E.W. (2003). Temporal patterns in bacterial communities in three temperate lakes of different trophic status. Microbial Ecology 46, 391-405.

Zwart, G., Crump, B.C., Kamst-van Agterveld, M.P., Hagen, F. \& Han, S.-K. (2002). Typical freshwater bacteria: an analysis of available 16S rRNA gene sequences from plankton of lakes and rivers. Aquatic Microbial Ecology 28, 141-155.

Zwart, G., van Hannen, E.J., Kamst-van Agterveld, M.P., van der Gucht, K., Lindström, E.S., Van Wichelen, J., Lauridsen, T., Crump, B.C., Han, S.-K. \& Declerck, S. (2003). Rapid screening for freshwater bacterial groups by using reverse line blot hybridization. Applied and Environmental Microbiology 69, 58755883.

Zwisler, W., Selje, N. \& Simon, M. (2003). Seasonal patterns of the bacterioplankton community composition in a large mesotrophic lake. Aquatic Microbial Ecology 31, 211-225.

\section{Author Profiles}

Eva S. Lindström is an assistant Professor at the Department of Limnology, Institute of Ecology and Evolution at Uppsala University, Sweden. She was awarded her PhD from the same department in 1999. Her main research interest is the biogeography of bacteria in inland waters, with the majority of her work focusing on Swedish lakes. She also has postdoctoral experience from the Institute of Limnology at the Austrian Academy of Sciences (OEAW) in Mondsee, Austria, and the Université du Québec à Montréal (UQÁM), Canada.

Jürg Brendan Logue is a $\mathrm{PhD}$ student in the Department of Limnology, Institute of Ecology and Evolution at Uppsala University, Sweden. Initially working on bacterial assemblages in stream sediments in the Swiss Alps, his research emphasis is now directed at describing distributional patterns of Swedish freshwater bacterioplankton, and on unravelling the processes underlying their biogeographical patterns. 